\title{
The New York State Labor History Association's Fourth Annual Meeting: A Participant's Critique
}

\section{Michael Frisch}

\author{
SUNY-Buffalo and Philadelphia Social History Project
}

Readers concerned about the relation between labor history and labor today may be interested in a report on this meeting, a small one-day conference held in Buffalo in June, 1979. In design, the meeting was an imaginative piece of public programming, aimed at bringing the world of historical scholarship and the world of contemporary unionism together. In execution, it became, at least to this participant, a frustrating failure that made these worlds seem very far apart, and made labor history itself seem peculiarly irrelevant to the present. It is worth reflecting on how and why commendable intentions led to such a result.

The conference deserves attention, additionally, because much of it focused on the method of oral history, a method currently fashionable among many historians anxious to recapture a more immediate and less mediated sense of the past, and also among labor and community organizers interested in the ways history can be used to generate a sense of social connection and collective action in the present. The problems of the conference help to highlight some dilemmas perhaps inherent in these approaches, and in the broader impulse to make of labor history something more than just another academic speciality. To the extent it is desirable to raise these dilemmas to the level of public discussion, I hope this critique will be taken as constructive in intent.

The program was carefully designed to attract a diverse audience, and to offer an informal yet focused exposure to labor history, past and present. Whatever the subsequent problems, it must be allowed that the organizers succeeded in these aims. The meeting began with a relaxed evening featuring a showing of Maria, an excellent made-for-TV Canadian movie about the difficulties of organizing immigrant women workers in a modern-day sweatshop. The conference itself opened the next morning with labor-management panel exploring contemporary industrial relations in the Buffalo area, offered as a case study for conditions in the declining industrial northeast. Late that afternoon, the confer- 
ence closed with a panel of historians, who discussed the theory and method of oral history, as both an historical and organizing tool. In between was a sort of combination session-a showing of a videotaped oral history of several women whose husbands had been centrally involved in an important 1937 strike at Buffalo's Republic Steel plant. This was accompanied by a free-flowing discussion involving two of these women, the audience, and the interviewer, who was an academic historian but, as the son and nephew, respectively, of his subjects and a small boy in their family at the time of the strike, a participant with vivid memories of his own.

Clearly, the conference had an ambitious program, one bringing together an historical perspective, documentary material, a concern with contemporary affairs, and an appreciation of the importance of both theory and method. Why, then, did it end up-as I know I am not alone in feeling it did-undercutting the relevance of history and exaggerating the gap between the academic and contemporary trade unionist perspectives?

The structure of the opening session made such an outcome almost inevitable, and for this I am afraid the program designers, rather than the participants, must bear the major responsibility. Where they might have arranged for a diverse panel examining the intended subject-labor relations in a declining industrial city like Buffalo-from a variety of vantages, what they offered was something quite different: the audience found itself facing a panel of union and management leaders all of whom were deeply involved in and committed to the Buffalo Erie County Labor-Management Council (LMC), which represents a very particular approach to modern labor relations. Their presentation consisted of a straightforward explanation of who they are, as an LMC, and what they do.

This informal briefing was far from uninteresting per se. But such a panel could neither invite nor prove terribly receptive to any more wide ranging, much less critical, discussion of current circumstances and what the LMC approach represents as a response to them. This was all the more frustrating because the presentation, and an accompanying handout by the LMC Executive Director, one of the panelists, were shot through with assumptions about labor history that were arguable at best and outrageous at worst. In brief, we were told that the LMC believes strikes, conflict, and contentious grieving to be associated with early, "immature," negative stage of the history of labor relations, a stage from which organized labor had in recent decades happily departed. Now, impelled by both the evolutionary momentum of history and the imperatives of current circumstances, we were told, labor had arrived at a higher plane of positive labor relations. In this realm, cooperation replaces conflicts, management acknowledges the union's right to exist, and labor accepts the responsibility to increase productivity, to "keep its militant elements restrained within the grievance procedure," and generally to seek what was offered as the culturally determined goal of the American worker: "to be part of the team, but not the manager."

With no input either from labor historians or from others in a trade union movement that has been anything but unanimous in endorsing either the facts or 
the values implied in the LMC notion of "maturity," the morning panel could hardly avoid projecting the view that the present was without significant choices for labor to weigh in assessing its position and strategy. With the ghosts of Sam Gompers and Marc Hanna hovering happily overhead, together, the present was offered as simply a moment in the maturation of a historically one-directional American labor movement.

This was, then, a curious start for a modern labor history conference. But surely, it seemed to many of us over lunch, the afternoon would provide some balance-the oral history of the 1937 Republic strike would raise different questions, and present a very different perspective.

It did, and yet in an important sense it didn't. While not an exemplary sample of oral history method, the videotape was successful in evoking the depth of the struggle involved in a depression-era industrial strike--struggle against the company, struggle within the working class community and even individual families, and struggle against the unrelenting hardships of the depression itself. The discussion following, with interviewer and subjects representing generations of one family, became extraordinarily engaging, especially in response to questions from younger members of the audience for whom these stories were new, shocking, and barely imaginable.

The problem, however, was that in all this there was no connection drawn, or even suggested, to the present. There was only the implied contrast between a primitive struggle for union existence then, and the secure world of established unions today. The very drama and depth of these past experiences, so vividly recounted, served in the absence of any more reflective discussion to emphasize the evolutionary distance organized labor has presumably travelled in the intervening time. This impression was reinforced by a curious aspect of the program itself: the interviewer, whose own 1937 recollections were offered in a vioce still charged with the anger of his family's struggle against scabs, goons, and the police, was the same man who, wearing his academic hat, had presided approvingly over the morning session, with its paen to the emergent mode of mature modern labor-management cooperation.

There is no real paradox here, of course. Implicit in the AM and more explicit in the PM was the message that the purpose of labor history is to tell us, in what has been called by some "the bad old days" nostalgia, where we once were, so we can better appreciate how far we have progressed. It might better be called the "You've come a long way, Baby" school of labor history. Now one may agree with this vision of history and the reasons for studying it, but this conference showed that it provides a remarkably poor basis for discussions between historians and current participants in the labor movement. By definition, in fact, it gives them very little of substance to talk about. And perhaps this is why the Buffalo conference generated so little real communication across disciplinary and occupational lines.

I hope these comments are not taken as simply an unkind attack on a perspective with which I happen to disagree. In fact, the issues I am discussing 
need to be pondered and better understood as well by those of us who see labor history as something more alive, complex, and instructive in the context of contemporary struggles. For there is a tendency in such circles to exaggerate the power of that history to inform the present: if only we can "get in touch with our history," it will flow through that touch into our world and our lives. This is an attitude especially prevalent at a time when there is a kind of industrial revolution in historical "production," with oral history playing the role of the flying shuttle, especially outside universities. In this context, the meeting of the New York State Labor History Association stands as a caution against expecting too much of these methods, and embracing them too uncritically. For as the conference showed, the same material and method can either connect us to the past or distance us from it, depending on how it is developed and understood; it can inform efforts for social change, or it can imprison us in culturally and/or historically bounded cells. This is true of any history, but is perhaps especially true of labor and working class history, where relevance can seem so much more selfevident. But genuine relevance does not lie in the working class focus itself, or the methodologies through which we study its history. As always, it lies in the questions we ask to that history, the answers we find, and the use to which we want to put them. The limitations of this ambitious yet frustrating conference stand as a powerful demonstration of this fundamental point. 